\title{
THE INNOVATIVENESS OF THE SERVICE SECTOR IN THE EUROPEAN UNION COUNTRIES
}

\author{
INNOWACYJNOŚĆ SEKTORA USŁUG W KRAJACH UNII EUROPEJSKIEJ
}

https://doi.org/10.34739/zn.2019.49.05

Kamil Decyk

Poland, University of Warmia and Mazury in Olsztyn, Faculty of Economics Science

Department of Economy Competitiveness

ORCID: 0000-0002-8590-4185, e-mail: kamil.decyk@uwm.edu.pl

\begin{abstract}
The subject of innovativeness is an interesting and unusually up-to-date research area in Poland and other countries. It is especially interesting to consider the situation in the service sector, whose specific character is largely related to the non-technological scope of innovativeness. With regards to such an outline of the research, the objective of this paper is to evaluate the level of the innovativeness of the service sector in EU countries. The research material in the paper was the Eurostat prepared database regarding the following: the level and type of innovative activity, as well as the degree of innovation in the EU services sector. In order to obtain the research goal, the method of analysis and criticism of literature, comparative analysis was used and the arithmetic mean was used to determine the levels of innovation. Based on the conducted research the top innovative level service sector countries include: France, the Netherlands, Italy, Spain and the United Kingdom. The medium level countries include: Germany, Sweden, Portugal and Poland. The service sectors of other countries were classified as low level innovativeness. The research, did not identify the influence of the service sector innovativeness on the innovativeness level of particular countries.
\end{abstract}

Keywords: innovativeness, level of innovative activity, innovation, service sector, European Union, Summary Innovation Index - SII

Streszczenie: Problematyka innowacyjności jest interesującym i niezwykle aktualnym obszarem badawczym w Polsce i na świecie. Szczególnie ciekawa jest sytuacja sektora usług, którego specyficzny charakter związany jest w znacznej mierze z innowacyjnością w zakresie nowości nietechnologicznych. W związku z określonym w ten sposób obszarem badawczym, za cel artykułu przyjęto ocenę poziomu innowacyjności sektora usług w krajach UE. Materiał badawczy w opracowaniu stanowiła baza danych opracowana przez Eurostat dotycząca: poziomu i rodzaju aktywności innowacyjnej, a także stopnia nowości innowacji wprowadzanych w sektorze usług UE. Do realizacji celu badawczego wykorzystano metodę analizy i krytyki piśmiennictwa, analizę porównawczą, a do wyznaczenia poziomów innowacyjności wykorzystano średnią arytmetyczną. Na podstawie zrealizowanych badań do państw o najwyższym poziomie innowacyjności sektorów usług zaliczono: Francję, Holandię, Włochy Hiszpanię oraz Wielką Brytanię. Średnim poziomem charakteryzowały się: Niemcy, Szwecja, Portugalia oraz Polska. Sektory usług pozostałych państw zaklasyfikowano do niskiego poziomu innowacyjności. W badaniach, nie zauważono wpływu innowacyjności sektora usług na poziom innowacyjności poszczególnych krajów.

Słowa kluczowe: innowacyjność, poziom działalności innowacyjnej, innowacje, sektor usług, Unia Europejska, Sumaryczny Wskaźnik Innowacyjności - SII

\section{Introduction - literature review}

The subject examined in this paper can be divided into two areas. The first one is the ever popular aspects related to innovativeness. The second one are issues associated with the service sector. This paper will first ponder the theoretical considerations of innovativeness, which can be defined and analyzed at different economic levels: macro-, mesoand microeconomic. The most popular and universal definition of innovativeness is that referring to the last of the levels mentioned - associated with the firm.
Innovativeness in this regard is understood as the inclination and ability of economic subjects to introduce new solutions, both of a technological character (product and process innovations) and non-technological - organizational and marketing innovations (Nowacki, 2010). According to Oslo Manual... (2008), apart from the physical goods, product innovations include services (in the literature often referred to as service innovation). For instance, Ojanen (2007) defines them as new or significant changes in current services, their creation or delivery processes. Tether, Howells (2007) understand 
„service innovations" as a successful completion of new ideas utilization.

The literature of the subject indicates, the level of an increase in the economy's efficiency is the result of application of knowledge and advanced technology by countries as well as regions and enterprises (Skórska, 2016, Dworak, Grzelak, 2017 For this reason, data of enterprises innovativeness can be used to assess its level in terms of particular sections, sectors and national economies. It is possible, because in order to evaluate the innovativeness level of a given economy, ratios ${ }^{1}$ reflecting the situation in, for instance, small and medium sized enterprises (SME) are widely used. These ratios may include: the share (in the analyzed population) of industrial enterprises, which in the past three years introduced technological innovation, the amount of expenditure on innovative activities, or the share of gross expenditure for research and development activity (R\&D) in the gross domestic product (GDP).

The service sector and related issues are the second of the main aspects described by research in this paper. According to J. Furasti's theory of three sectors of the economy (Rogoziński, 2000), the role of agricultural and industrial sectors is changing and they are increasingly less significant for the development of a country's economy, with the service sector becoming more significant at the same time (Aboal et al. 2015). Therefore, innovations determining the level of the service sector innovativeness may occur in one of the four phases of sector development. This is an interesting problem (Flejterski et al., 2005):

-initial - no requirement for high occupational qualifications for the provision of services,

- growth - requires higher qualifications than the initial period,

- industry facilitation and consumption growth consumption and service activities are developed in synergy,

- development - mainly services based on high technology application.

Because of the use of advanced technologies, innovations are most likely to occur in the last of these development steps. This phase is observed only in highly developed countries.

The issue linking both the above presented research dimensions is not popular nor frequently

\footnotetext{
${ }^{1}$ A ratio, measure and indicator are not interchangeable terms. A ratio is for instance: "the number expressing a percentage relation of the analyzed factor size to the assumed base", while an indicator is a term typical for chemistry. Regarding the data presented in this study, the use of each of these terms is not fully correct. It is necessary to bear this in mind in the later parts of this
}

occurring in the subject literature. Because of that, it presents an especially interesting research niche (Menor et al., 2002; Papastathopoulou, Hultink, 2012). At the same time, recent years saw the study of innovativeness and innovations research in the service sector becoming a significant research field from the cognitive point of view (Menor, Roth, 2007). The low popularity of the subject in question results from three basic factors, whose roots should in the first place be traced back to economic theories. Although the inquiry into the service sector started from the classic era and A. Smith, who was skeptical about the services' function in the economy, counting them as unproductive activities, the former economic model (albeit without services) sufficiently explained the determinants of economic activities (Smith 1954). The point of view presented by A. Smith was criticized by J.C.L. Sismonde, Say, and A. Marshall, who unanimously perceived the importance of services in the context of economic development. Nowadays, the position of J.A. Schumpeter towards innovations having the characteristics of services is widely supported by Flikkema et al. (2007), Toivonen and Tuominen (2009). They highlight that innovations have a significant impact on economic development. A similar view is presented by Dotzel et al. (2013). The mentioned scholars recognize that innovations in services and the development of new or improved intangible solutions are the foremost factors driving the economic results of particular countries.

The second reason of the research subject considered in this paper was directly related to the transformation of the economy towards so called „servitization"2 in Western Europe, the United States and also Central and Eastern Europe in the $X X^{\text {th }}$ century. The largest growth in significance of the service sector occurred at the beginning of the $\mathrm{XX \textrm {X } ^ { \mathrm { st } }}$ century. The significance of the service sector in the economy is determined by the share of services in GDP creation (Szymańska, 2015) or the gross value added, which in the EU in 2007, in $72 \%$ came from services. (Challenges... 2009).

The third and final confirmation of the uniqueness of the research presented in this paper is correlated with the classification of innovations. Organizational and marketing-related novel solutions employed in the service sector became considered as innovations as late as 2008 (third edition of Oslo

study. In order to facilitate the analysis of the data, these terms will be used interchangeably in this study.

2 The process of the development of a service civilization resulting from the growing influence of the service sector in the national economy (Lichniak, 2010). 
Manual, which is recognized as the most universal and widely applicable set of rules related to measurement as well as other subjects associated with innovativeness and innovations $\left.{ }^{3}\right)$. In earlier years, they were not recognized as those, which testified to and influenced the level of innovativeness. The novelties in organization and marketing are largely the basic source of innovativeness in service corporations (Skórska, 2016; Gallouj, 2002). Apart from these types of novelties, the literature on the subject (Barras, 1986; OECD 2005) also points to the equally crucial role of process innovations.

\section{Methodology and theoretical basis}

The objective of the research in this paper is the evaluation of the level of innovativeness of the service sector in the EU member states. This estimation was achieved based on the data related to the innovative activity of service enterprises gained from the Eurostat (current innovation data are from 2016).

For the empirical part of the study, among numerous definitions of innovativeness, the one presented by Dobni (2010) was chosen. According to it innovativeness expresses the willingness and inclination toward being innovative and also determines the ability to introduce new products, services or ideas, until their launch, which creates an improvement in business results, including for instance, financial results in the form of profit or revenue. The quoted definition is wider than that presented in Oslo Manual.

The obejct of the research presented in this paper were innovativeness parameters (criterions, data), demonstrating the level of innovative activity conducted by the service sector enterprises. For the purpose of the analysis. For the analyses in the study, the following data were used:

- the level of innovative activity,

- the level of innovative activity in the scope of product and/or process (technological activity),

- lack of innovative activity.

Innovative activity is understood as: the activity in the scope of development, financial and commercial actions, which, in consequence are supposed to lead to the introduction of innovations, or at least become an essential element in introducing innovations in the future (Oslo Manual..., 2005). It means that innovative activity enterprise is the one, which is in the process of developing novelty solutions with the features of an innovation (Działalność innowacyjna przedsiębiorstw..., 2017).

The presented definition of an innovative activity included terms such as product, process, organizational and marketing innovations. These changes can be classified in two groups: technological innovations and non-technological (Table 1).

Table 1. Classification of innovations

\begin{tabular}{|c|c|c|c|}
\hline \multicolumn{4}{|c|}{ Innovation type } \\
\hline \multicolumn{2}{|c|}{ Technological } & \multicolumn{2}{|c|}{ Non-technological } \\
\hline Product innovation & Process innovation & Organizational innovation & Marketing innovation \\
\hline $\begin{array}{l}\text { - } \text { market launch of new or } \\
\text { substantially improved goods } \\
\text { or services, } \\
\text { - changes in features or } \\
\text { purpose of use, } \\
\text { - in the case of services, } \\
\text { innovation can be e.g.: } \\
\text { introducing totally new } \\
\text { services, improved provision } \\
\text { of services, additional } \\
\text { functions or features of } \\
\text { existing services. }\end{array}$ & $\begin{array}{l}\text { - introducing new or } \\
\text { substantially improved } \\
\text { production or distribution } \\
\text { methods, goods and } \\
\text { services support } \\
\text { operations, } \\
\text { - process innovations } \\
\text { include e.g. new or } \\
\text { substantially improved } \\
\text { creation and provision of } \\
\text { services. }\end{array}$ & $\begin{array}{l}\text { - the first time } \\
\text { implementation by a firm } \\
\text { of a new organizational } \\
\text { method in business } \\
\text { practices accepted by a } \\
\text { firm (operation rules), in } \\
\text { the organization of a } \\
\text { workplace or } \\
\text { relationships with the } \\
\text { firm's surrounding. }\end{array}$ & $\begin{array}{l}\text { - } \text { implementation of a } \\
\text { new concept or } \\
\text { marketing strategy, } \\
\text { which substantially } \\
\text { differs from the } \\
\text { previously used by } \\
\text { the firm marketing } \\
\text { methods. }\end{array}$ \\
\hline
\end{tabular}

The subject literature certainly presents many more ways of the classification of innovation types. the way presented in Table 1 is the most universal and conforming to the rules set in the Oslo Manual,
3 Oslo Manual. Zasady gromadzenia i interpretacji danych
dotyczących innowacji. OECD/Wspólnoty Europejskie 2005.
Warszawa PARP, 2008.
The third edition of the Oslo Manual, which is considered to be the most universal and generally applicable set of guidelines for measurement and issues related to innovativeness and innovation. 
it is also compliant with the methodology used for the Eurostat database making and, moreover, it is compatible with the methodical assumptions made in The Central Statistical Office (in Polish: GUS) statistics.

The effects of innovative activity determining the level of the innovativeness level in the study were also analyzed based on the parameters relative to:

- the number or enterprises introducing a certain kind of innovation,

- the number of enterprises introducing product innovations with a specified degree of novelty.

Within the scope of the first of the mentioned parameters it was possible to differentiate three categories based on the number of enterprises: innovative, technologically innovative and nontechnologically innovative. The scale of the innovative novelties was examined based only on the product (including services), because of the unavailability of organizational and marketing innovations in the Eurostat database. In the scope of this parameter, innovations were classified into three scales. Global scope novelties - products unknown in the world, market level ${ }^{1}$ - products, new on a specific market, but known in the world, and in the firm level - products known in the world and the market, but totally new or at least largely improved from a company's perspective. In the context of the level of innovativeness, the most favourable situation is introducing innovations at a world level, because it is the widest scale of novelties among the described three.

The subject of this study was the service sector of particular EU member states. According to the research methodology applied by GUS in Poland and in line with Polish Classification of Activities (in Polish: PKD) from 2007 r., this sector contains eight sections of the national economy, which are identified by consecutive alphabet letters $(\mathrm{H}-\mathrm{N})$.

To achieve the research objective, a method of in-depth analysis and critique of domestic and foreign literature was used. This led to determining, among others, the definitions associated directly with the subject of innovativeness. Based on this method, parameters to the assessment of innovativeness were chosen. The research also included the analysis of secondary data associated with the parameters of innovativeness, present in the Eurostat. The innovativeness level was evaluated using the statistical method, the arithmetic mean value was especially applied. It classifies countries according to criteria such as: innovation active enterprises, innovative enterprises and enterprises launching the first innovation product, which is unknown in the world. On the ground of these parameters, three levels of innovativeness of the service sector were determined: high, average and low. The first one included countries that obtained values of parameters above the average. The values oscillating around the average were characteristic for the service sectors with an average level of innovativeness. Parameters definitely below the average indicated a low level of innovativeness. The data according to the classification were supplemented with detailed information, whcich allowed for a more comprehensive approach to the discussed problem (e.g. analysis of innovativeness was made in the area of non-technologically innovative enterprises, enterprises active only in the scope of product/process).

To analyze the innovativeness level, apart from the arithmetic mean, the comparative analysis was also performed. The material in this field, apart from personal research, also included research conducted by the GUS in Poland and information from the latest European Innovation Scoreboard (EIS) report of 2019 on innovation in EU countries.

\section{Results and discussion}

To evaluate the level of innovativeness pertaining to particular countries' service sectors, the analysis ought to be started with the ratio of the most general nature, which proved the innovative activity. The data were ranked in descending order starting with the numer of innovative activite enterprises (Table 2).

\footnotetext{
${ }^{1}$ Methodical assumptions of Eurostat database do not explicitly define the market. Oslo Manual..., (2005, p. 58) also does not precisely define market level novelties. It recognized the market as: "the firm and competitors, whereby the market can contain a
}

geographical region or a product line. Consequently, the territorial scope of the market novelties depends on each firm's definition of its market, which means that the market can include both domestic and foreign firms". 
Decyk K., THE INNOVATIVENESS OF THE SERVICE SECTOR IN THE EUROPEAN UNION COUNTRIES, Zeszyty Naukowe Uniwersytetu Przyrodniczo-Humanistycznego w Siedlcach Nr 122, Seria: Administracja i Zarządzanie (49) 2019

Table 2. The level of innovativeness of the service sector in the EU member states in 2016 (number of enterprises)

\begin{tabular}{|c|c|c|c|c|}
\hline No. & Country & $\begin{array}{l}\text { Innovative active } \\
\text { enterprises }\end{array}$ & $\begin{array}{l}\text { Innovative inactive } \\
\text { enterprises }\end{array}$ & $\begin{array}{c}\text { Innovative active enterprises } \\
\text { - only in product and/or } \\
\text { process scope }\end{array}$ \\
\hline 1 & France & 48400 & 47432 & 6821 \\
\hline 2 & United Kingdom & 35816 & 35356 & 9520 \\
\hline 3 & Italy & 29770 & 36635 & 5109 \\
\hline 4 & Germany & 22695 & 14870 & 4926 \\
\hline 5 & Spain & 21744 & 55061 & 3320 \\
\hline 6 & the Netherlands & 17045 & 19479 & 7446 \\
\hline 7 & Sweden & 9479 & 12630 & 1013 \\
\hline 8 & Portugal & 5856 & 2428 & 1377 \\
\hline 9 & Poland & 4829 & 21264 & 2105 \\
\hline 10 & Czech Republic & 4117 & 5907 & 928 \\
\hline 11 & Denmark & 3395 & 3822 & 468 \\
\hline 12 & Austria & 2767 & 2092 & 432 \\
\hline 13 & Ireland & 2458 & 2072 & 285 \\
\hline 14 & Belgium & 2363 & 1614 & 860 \\
\hline 15 & Hungary & 2326 & 5672 & 665 \\
\hline 16 & Croatia & 2021 & 2406 & 258 \\
\hline 17 & Bulgaria & 1516 & 5334 & 372 \\
\hline 18 & Finland & 1493 & 1187 & 393 \\
\hline 19 & Romania & 1432 & 12931 & 351 \\
\hline 20 & Greece & 1313 & 1240 & 261 \\
\hline 21 & Lithuania & 1095 & 1280 & 378 \\
\hline 22 & Slovakia & 974 & 2449 & 241 \\
\hline 23 & Slovenia & 793 & 1353 & 208 \\
\hline 24 & Latvia & 775 & 1943 & 172 \\
\hline 25 & Estonia & 746 & 1090 & 376 \\
\hline 26 & Luxembourg & 664 & 303 & 104 \\
\hline 27 & Malta & 393 & 1083 & 50 \\
\hline \multirow[t]{3}{*}{28} & Cyprus & 205 & 354 & 37 \\
\hline & Sum & 226480 & 299287 & 48476 \\
\hline & Mean & 8089 & 10689 & 1731 \\
\hline
\end{tabular}

Source: own research based on Eurostat: inn_cis10_bas, 6.08.2019.

Based on the data presented in Table 2, it is noticeable that France is the case with the top performance. First, this country's service sector boasted the highest number of innovative enterprises $-48400(21,37 \%$ of all enterprises of this type), and secondly, this type of enterprise was more common than innovative-inactive firms (47 432). Such a relation between innovative activity parameters should be deemed favourable, as it positively testifies to the level of innovativeness of the service sector. The inverse ratio would be considered unfavourable and would provide a lower level of innovation. A greater number of innovation active subjects compared to non-active ones were noted in 9 countries: the UK, Germany, Portugal, Austria, Ireland, Belgium, Finland, Greece and Luxembourg. The source of innovative activity in some of these countries was some of the highest ratios related to the expenditure on research and development (R\&D). In the leading position was France, this ratio amounted to 1,42 , while the top EU performer was Sweden - 2,42. Among the above countries, in which the innovative active subjects prevailed, the indicator in question was highest in Austria $(2,22)$ and Germany $(2,09)$. Denmark performed at 1,97, Finland at 1,80, with Belgium at 1,76. Comparing the EIS results with my own research data, it is worth to note the occurrence of dependency between the amount of $R \& D$ expenditure and the innovative activity of the service sector enterprises. In countries where this expenditure was high, innovation activity in the services sector was greater, which is consistent with the subject literature (Hall 2011; Mairesse, Mohnen 2002). In these states the advantage of innovation active service companies over non-innovative service companies was also observed. 
Basically, the average number of innovation active enterprises in the EU, based on 28 member states, amounted to 8,089 . The services sectors of the first seven of the countries analyzed were seen to be higher than the average innovation activity. The remaining group was observed to have lower activity than the EU average.

To complement the conducted analysis, a compilation of the best service sector firms in terms of their activity in technological innovation was utilized. On this basis, it can be seen that the UK services sector has the greatest activity, while the Netherlands and France followed in the ranking.
Technological activity in seven countries was considered to exceed the EU average - 1, 731. In addition to the aforementioned countries, Italy, Germany, Spain and Poland were also included. The sectors of the other member states ranked below average.

The next ranking, used to assess the level of innovativeness of the service sector, was conducted in terms of the number of innovation active enterprises representing particular countries' sectors. Apart from these, the service sector subjects introducing technological and non-technological innovations were examined (Table 3 ).

Table 3. Type of innovative activity of the service sector in the EU members in 2016 (number of enterprises)

\begin{tabular}{|c|c|c|c|c|}
\hline No. & Country & Innovative enterprises & $\begin{array}{c}\text { Technological } \\
\text { innovative enterprises }\end{array}$ & $\begin{array}{c}\text { Non-technological } \\
\text { innovative enterprises }\end{array}$ \\
\hline 1 & France & 47207 & 27714 & 18234 \\
\hline 2 & United Kingdom & 34429 & - & 10795 \\
\hline 3 & Italy & 29187 & 19483 & 9123 \\
\hline 4 & Germany & 21822 & 14542 & 5513 \\
\hline 5 & Spain & 21088 & 8307 & 12196 \\
\hline 6 & the Netherlands & 16479 & 12562 & 3695 \\
\hline 7 & Sweden & 9310 & 5222 & 1929 \\
\hline 8 & Portugal & 5795 & 4776 & 939 \\
\hline 9 & Poland & 4654 & 3541 & 1048 \\
\hline 10 & Czech Republic & 3977 & 2798 & 1046 \\
\hline 11 & Austria & 2713 & 1943 & 742 \\
\hline 12 & Ireland & 2397 & - & 725 \\
\hline 13 & Hungary & 2263 & 1490 & 702 \\
\hline 14 & Belgium & 2004 & 1635 & 165 \\
\hline 15 & Croatia & 1998 & 1210 & 758 \\
\hline 16 & Bulgary & 1455 & 883 & 553 \\
\hline 17 & Finland & 1450 & 1284 & 138 \\
\hline 18 & Romania & 1408 & 661 & 734 \\
\hline 19 & Greece & 1289 & 1032 & 231 \\
\hline 20 & Lithuania & 1081 & 884 & 184 \\
\hline 21 & Slovakia & 935 & 620 & 304 \\
\hline 22 & Latvia & 757 & 466 & 269 \\
\hline 23 & Slovenia & 737 & 501 & 215 \\
\hline 24 & Estonia & 720 & 649 & 72 \\
\hline 25 & Luxembourg & 649 & 414 & 213 \\
\hline 26 & Malta & 375 & 231 & 129 \\
\hline 27 & Cyprus & 205 & 169 & 35 \\
\hline \multirow[t]{3}{*}{28} & Denmark & - & - & 1013 \\
\hline & Sum & 216384 & 113017 & 71700 \\
\hline & Mean & 8014 & 4521 & 2561 \\
\hline
\end{tabular}

Source: own research based on Eurostat: inn_cis10_type, 6.08.2019

The highest number of innovation active enterprises in the service sector was noted in France (47 207), which amounts to $21,82 \%$ of all EU enterprises of this type. The same situation occurred in the case of technological innovative enterprises -
$27714(24,52 \%)$ and non-technological - 18234 $(25,43 \%)$. The other extreme was occupied by Cyprus, where in 2016 only $205(0,09 \%)$ of innovative service sector firms were noted. The first seven countries had a number of innovative enterprises 
higher than the EU's average (8 014). According to them the European Innovation Scoreboard..., (2019) was characterized by a substantial percentage of innovative enterprises in: Italy - 38,8\%, the Netherlands $-35,0 \%$, and Sweden $-33,5 \%$. The largest percentage of innovative enterprises introduced so-called in-house innovations in Portugal $(51,2 \%)$. On account of this result, it is worth observing the disparity between my own research and the EIS data regarding innovative enterprises.

Expanding the analysis regarding the type of innovative activity it is apparent that the first seven countries (Table 3), were characterized by a higher than average number of technological innovative enterprises in the service sector (4 521). They were the same countries that dominated in terms of the highest ratio of innovative enterprises. The first six countries outlined in the ranking were also noted to have a higher than average number of firms introducing non-technological innovations (2 561).

Based on the data in Table 3, a tendency that occurred in every country, except for Spain, can also be observed. This regularity is associated with the dominance of product and/or process innovative enterprises over those that introduced an organizational and/or marketing innovation. The exception was Spain, where a higher activity of innovative enterprises in the field of non-technological than technological innovations was observed. This difference was almost 1,5 times. The greatest advantage of technological innovations over nontechnological innovations occurred in Finland (9,3 times more technological innovations). A large and distinctive disproportion in this matter also occurred in Estonia (9 times). This score can at first seem to be in contradiction to the subject literature, which usually highlights the domination of non-technological innovations over technological innovations (Innowacje w sektorze..., 2011; Gallouj, 2002). The research realized in earlier years in Poland proves that marketing and organizational innovations in the service sector exceed product and process innovations (Skórska, 2016; Kłosiewicz-Górecka, 2018).

There may be several reasons for the advantage of technological innovation over nontechnological innovation in my own research. First, the intensification of activities in the scope of product innovations of the service character may have been the reason for this phenomenon (e.g. internet services, new forms of guarantee or a new system of customer-controlled supply system). The second reason was the type of innovations introduced in the processes. Process innovations, being the focal point of interest in this section of the paper, according to the Oslo Manual..., (2005), emerge in supply and/or operations domain, and can be resultant from, for instance, the use of: electronic settlement systems, supply chain flow enhancing programming tools, or portable scanners/computers for goods and in-stock registration. These examples of innovative process solutions have a universal character and can be used to the same degree and at the same frequency both in industrial firms (to a larger extent inclined towards production) and service firms.

For instance, according to GUS data in Poland (Działalność innowacyjna przedsiębiorstw 2017) in 2014-2016, the largest proportion of service enterprises introduced process innovations $-10,4 \%$. On the other hand, non-technological changes constituted a smaller proportion: organizational $7,6 \%$, and marketing $-7,2 \%$. These data are consistent with the compiled research material presented in this paper and confirm that a conclusion about the dominance of non-technological innovations over technological innovations in the service sector cannot be inferred.

A significant criterion for the differentiation of the level of innovation was a novelty rank, also referred to as the reach of innovations introduced. In line with this criterion, the conducted analyses distinguished: world level, market level and the firm level (firm innovation). Table 4 contains EU member states' service sectors ranked in descending number of enterprises, which introduced a product innovation unknown at world level.

The highest rank of innovation novelty from among all the analyzed countries was the feature of the French service sector, which substantially dominated all others. As many as 7380 service enterprises that introduced a worldwide innovation were identified in it. It accounted for $43,81 \%$ of all worldwide innovations introduced in the service sector in the whole EU. The second were the Netherlands and Italy - the third - countries which exposed similar activity in this regard (respectively: 2641 and 2477 enterprises). The next group of countries with a slightly lower ratio includes Portugal, Poland and Germany. At the same time, in the case of Poland, it was the best result among all the parameters discussed in the study related to the level of innovativeness. The share of other countries' service sectors in introducing world level innovations was negligent and oscillated between 2,59\% (Sweden) and 0,00\% (Estonia), which translates to 432 and 0 enterprises. The countries at positions in ranking lower than Portugal achieved a lower number of worldwide innovations than the EU's average (887). It can be concluded, that the top performing service sectors in terms of the ratio in question are those in: France, the Netherlands, Italy and Portugal. 
Table 4. Product innovation novelty rank introduced in EU member states' service sectors in 2016 (number of enterprises)

\begin{tabular}{|c|c|c|c|c|}
\hline No. & Country & $\begin{array}{l}\text { First product innovation } \\
\text { unknown at world level }\end{array}$ & $\begin{array}{l}\text { Product innovation } \\
\text { at market level }\end{array}$ & $\begin{array}{l}\text { Product innovation } \\
\text { at firm's level }\end{array}$ \\
\hline 1 & France & 7380 & 12068 & 13618 \\
\hline 2 & the Netherlands & 2641 & 5249 & 5185 \\
\hline 3 & Italy & 2477 & 7236 & 10982 \\
\hline 4 & Portugal & 1081 & 1750 & 2392 \\
\hline 5 & Poland & 717 & 821 & 1143 \\
\hline 6 & Germany & 661 & 2491 & 9604 \\
\hline 7 & Sweden & 436 & 2492 & 2412 \\
\hline 8 & Hungary & 301 & 583 & 717 \\
\hline 9 & Croatia & 260 & 397 & 651 \\
\hline 10 & Romania & 229 & 203 & 327 \\
\hline 11 & Belgium & 178 & 879 & 1056 \\
\hline 12 & Slovakia & 105 & 278 & 239 \\
\hline 13 & Latvia & 103 & 251 & 235 \\
\hline 14 & Slovenia & 101 & 257 & 253 \\
\hline 15 & Bulgaria & 92 & 498 & 515 \\
\hline 16 & Malta & 37 & 58 & 97 \\
\hline 17 & Cyprus & 30 & 93 & 112 \\
\hline 18 & Greece & 15 & 461 & 571 \\
\hline 19 & Czech Republic & - & 1084 & 1526 \\
\hline 20 & Estonia & 0 & 210 & 282 \\
\hline 21 & Ireland & - & 648 & 881 \\
\hline 22 & Spain & - & 1894 & 3289 \\
\hline 23 & Lithuania & - & 265 & 457 \\
\hline 24 & Luxembourg & - & 125 & 204 \\
\hline 25 & Austria & - & 898 & 1119 \\
\hline 26 & Finland & - & 516 & 824 \\
\hline 27 & United Kingdom & - & 6494 & 14948 \\
\hline \multirow[t]{3}{*}{28} & Denmark* & - & - & - \\
\hline & Sum & 16844 & 48199 & 73639 \\
\hline & Mean & 887 & 1785 & 2727 \\
\hline
\end{tabular}

${ }^{*}$ no data in the database

Source: own research based on Eurostat: inn_cis10_prodn, 6.08.2019

The level of the service sector innovativeness may be confirmed by the proportion of market innovations in relation to company innovations. It correlates positively with the higher level of innovativeness of a specific subject. It is necessary to detect that within the data presented in Table 4, in the case of each of the EU countries, the prevailing innovations were firm level product innovations. Five countries were an exception to this rule: the Netherlands, Sweden, Slovakia, Latvia and Slovenia. These countries were observed, as previously mentioned, to have a favourable relation of market level to firm level innovations. The described relation does not frequently occur and is characteristic for companies/sectors with a higher level of innovativeness. The highest favourable relation occurred in Slovakia, where 257 enterprises introduced a market level innovation, and 253 - at firm level. It was indeed a difference of a mere $0,02 \%$, nonetheless, it may testify to positive symptoms regarding the level of innovative activity. In the case of Slovakia, which was ranked number 1 in the European Innovation Scoreboard..., (2019) regarding the parameter of new and modernized products sales value - innovative both at the market and the firm level. According to the aforementioned document, the value of this criterion amounted to 20,27. Countries which, like Slovakia were characterised by a relatively high value of parameter,include: France, Italy and the United Kingdom. In the case of these countries, however, it resulted directly from a large number of innovative enterprises in the scope of product innovations. The highest sales value in these countries was noted in the United Kingdom - 15,53, 
next in Italy - 12,30 and in France - 9,85 (European Innovation Scoreboard..., 2019).

Using a comparative analysis of the service sector innovativeness with the economy innovativeness, expressed in the Summary Innovation Index, discrepancies were noted. Major differences in the conducted service sector research in relation to the level of innovativeness of entire economies described by SII referred to Denmark, Sweden, Finland and Luxembourg. The economies of the first three above countries were recognized in EIS as the most innovative in the EU - innovation leaders, while in my own research they were ranked as the countries with the lowest level of service sector innovativeness. Moreover in my own research and data from the EIS report there were substantial differences in the following parameters: the type of innovative activity of the service sector and novelty scale of product innovations of the said sector.

\section{Conclusions}

To summarize, it is necessary to conclude that the highest level of innovativeness of the service sector among all EU member states was observed in France. Service enterprises in France were characterized by the highest level of activity in terms of innovations, the highest number of innovative enterprises were noted there, and innovations at the world level are dominated decisively, compared to other EU countries.

A comprehensive inquiry into the conduced analyses of all parameters determining the level of innovativeness leads to the observation that each of their, highest level was in France, the Netherlands, Italy, Spain and the United Kingdom. Based on the conducted research it can be concluded that the service sectors of these countries were a group with a high level of innovation. The countries where the average level of innovativeness of the services sector was identified included: Portugal, Poland, Germany and Sweden. Low, and at the same time the lowest level of innovativeness, characterized the service sectors of other countries. Research also notes that technological innovation dominates over non-technological innovation in all EU countries. Spain and Romania were the only exceptions.

Beside identifying innovation levels, on the basis of conducted research, in countries such as Sweden, Austria, Germany, or Finland, a correlation between expenditures on R\&D activity and innovation activity has been noted. In countries with high R\&D expenditures, the activity in the field of innovation activities was at the same time at a higher level. Additionally, comparing the parameters from the EIS report with the results of my own research in the field of services, the impact of innovation in the service sector on the development and condition of innovation in the whole economy was not visible. It can be inferred, therefore, that in the case of innovation, the "servicisation" mentioned in the theoretical considerations did not occur. The issue covered in this paper can stimulate expansion of the research into the service sector innovativeness in two dimensions. First, in order to complement the research in this scope in the future, it is worth to attempt to evaluate and characterize the EU's service sector innovativeness from the innovative potential perspective (R\&B spending, innovative activity expenditure and financial sources, etc.). Secondly, the subject covered in this paper, as Ostrom et al. (2015, p. 135) point out can be furthered by identification of "the interrelationships among service-product, service-process, and business-model innovation".

\section{References}

Aboal, D., Bravo-Ortega, C., Crespi, G. (2015). Innovation in the Services Sector, Emerging Markets Finance \& Trade, No. 51, 537-539.

Barras, R. (1986). Towards a theory of innovation in services. Research Policy, Vol. 15, 161-173.

Challenges for EU support to innovation in services - Fostering new markets and jobs through innovation 2009. Bruksela: Commission of The European Communities, www.ec.europa.eu, dostęp on-line: 05.04.2019 r.

Dobni, C.B. (2010). The Relationship Between an Innovation Orientation and Competitive Strategy. International Journal of Innovation Management 2010, Vol. 14, No. 2, 331-357.

Dotzel, T., Shankar, V., Berry L.L. (2013). Service innovativeness and firm value. Journal of Marketing Research 50 (2), 259-276.

Dworak, E., Grzelak, M.M. (2017). Innowacyjność polskiej gospodarki według rankingów międzynarodowych. Studia PrawnoEkonomiczne, t. CIV, 255-268, Łódzkie Towarzystwo Naukowe.

Działalność innowacyjna przedsiębiorstw w latach 2014-2016. Urząd Statystyczny, Szczecin, 2017.

European Innovation Scoreboard (EIS), Luxembourg, Publications Office of the European Union, 2019.

Flejterski, S., Panasiuk, A., Perenc, J., Rosa, G. (2005). Współczesna ekonomika usług. Warszawa: Wydawnictwo Naukowe PWN.

Flikkema, M., Jansen, P. Van Der Sluis, L. (2007). Identifying Neo-Schumpeterian innovation in service firms: A conceptual essay with a novel 
classification. Economics of Innovation \& New Technology, 16(7)/2007, 777-780.

Gallouj, F. (2002). Innovation in services and the attendant old and new myths. The Journal of Socio-Economics, Vol. 31, 137-154.

Hall, B.H. (2011) Innovation and Productivity. Nordic Economic Policy 2, 167-204.

Innowacje $w$ sektorze usług. Warszawa: Wydawnictwo PARP, 2011.

Kłosiewicz-Górecka, U. (2018). Innowacyjność przedsiębiorstw usługowych. Marketing i Rynek nr 9/2018, 6-18. Warszawa.

Kraśnicka, T. (2013). Innowacyjność przedsiębiorstw - uwarunkowania organizacyjne. Studia Ekonomiczne, Zeszyty Naukowe Uniwersytetu Ekonomicznego w Katowicach nr 136, 165-179.

Lichniak, I. (Ed.). 2010. Serwicyzacja polskiej gospodarki. Warszawa: Wydawnictwo Szkoła Główna Handlowa.

Mairesse, J., Mohnen P. (2002). Accounting for Innovation and Measuringlnnovativeness: An Illustrative Framework and an Application. American Economic Review, 92(2), 226-230.

Menor, L.J., Tatikonda, M.V., Sampson, S.E. (2002). New service development: areas for exploitation and exploration. Journal of Operations Management, Vol. 20, No. 2, 135-157.

Menor, L.J., Roth, A.V. (2007). New service development competence in retail banking: construct development and measurement validation. Journal of Operations Management, Vol. 25, 825-846.

Nowacki, R. (Ed.). (2010). Innowacyjność w zarządzaniu a konkurencyjność przedsiębiorstwa. Warszawa: Wydawnictwo Difin.

OECD. (2005). Promoting innovation in services. Paris, Committee for Scientific and Technological Policy.

Ojanen, V. (2007). On the Innovation Capacity of Technology Related Knowledge-Intensive Business Services. A Case Study of the Technology and Engineering Consulting (TEC) Sector in Singapore. Research Report, 191. Lappeenranta, Lappeenranta University of Technology.
Oslo Manual. Zasady gromadzenia i interpretacji danych dotyczących innowacji. OECD/ Wspólnoty Europejskie 2005. PARP, Warszawa, 2008.

Oslo Manual. Zasady gromadzenia i interpretacji danych dotyczących innowacji. Paryż, OECD, 2005.

Ostrom, A.L., Parasuraman, A., Bowen, D.E., Patrício, L., Voss, C.A. (2015). Service research priorities in a rapidly changing context. Journal of Service Research, Vol. 18, No. 2, 127-159.

Papastathopoulou, P., Hultink, E.J. (2012). New service development: an analysis of 27 years of research. Journal of Product Innovation Management, Vol. 29, No. 5, 705-714.

Rogoziński, K. (2000). Usługi rynkowe. Poznań: Wydawnictwo Akademii Ekonomicznej w Poznaniu.

Skórska, A. (2016). Innowacyjność sektora usług w Polsce. Studia Ekonomiczne, Zeszyty Naukowe Uniwersytetu Ekonomicznego w Katowicach nr 272, 153-164.

Smith, A. (1954). Badania nad naturą i przyczynami bogactwa narodów. Warszawa: Wydawnictwo Naukowe PWN.

Szczukocka, A. (2015). Rozwój usług w wybranych krajach na świecie. Wiadomości Statystyczne nr 10, 75-84. Główny Urząd Statystyczny, Polskie Towarzystwo Statystyczne.

Szymańska, E. (2015). Serwicyzacja gospodarki jako źródło jej transformacji. Optimum: Studia Ekonomiczne nr 1(73)2015, 97-109.

Tether, B., Howells, J. (2007), Changing Understanding of Innovation in Services. Innovation in Services, No. 9, 21-60.

Toivonen, M., Tuominen, M. (2009). Emergence of innovations in services. The Service Industries Journal, 29(7)/2009, 887-902. 